\title{
Design Study and Cost Estimate for an Assured Isolation Facility in Texas
}

\author{
National Low-Level Waste \\ Management Program
}

August 1999 


\section{DISCLAIMER}

This information was prepared as an account of work sponsored by an agency of the U.S. Government. Neither the U.S. Government nor any agency thereof, nor any of their employees, makes any warranty, express or implied, or assumes any legal liability or responsibility for the accuracy, completeness, or usefulness of any information, apparatus, product, or process disclosed, or represents that its use would not infringe privately owned rights. References herein to any specific commercial product, process, or service by trade name, trademark, manufacturer, or otherwise, does not necessarily constitute or imply its endorsement, recommendation, or favoring by the U.S. Government or any agency thereof. The views and opinions of authors expressed herein do not necessarily state or reflect those of the U.S. Government or any agency thereof. 


\title{
Design Study and Cost Estimate for an Assured Isolation Facility in Texas
}

\author{
R. D. Baird \\ N. Chau \\ B. C. Rogers
}

Published August 1999

\author{
Prepared by \\ Rogers \& Associates Engineering Corporation \\ P.O. Box 330 \\ Salt Lake City, UT 84110-0330
}

Prepared for

National Low-Level Waste Management Program

Idaho National Engineering and Environmental Laboratory Idaho Falls, ID 83415

Under DOE Idaho Operations Office

Contract DE-AC07-94ID13223 


\begin{abstract}
The optimized assured isolation facility (AIF) consists of waste shipping containers being placed inside steel-reinforced concrete overpacks, which are, in turn, placed in steel-reinforced concrete vaults without an earthen cover system. The concrete vaults are designed to remain in service for hundreds of years, with the aid of ongoing active maintenance. This will be required since the facility will remain under license as long as waste is present in the facility.

The estimated present value of life-cycle costs total about $\$ 318$ million. Of this amount, over 30 percent is attributable to the need to accumulate the financial assurance fund which allows future management options to be implemented.

The charge for waste received at the AIF in order to recover all costs and ensure proper facility function following the waste acceptance period was calculated for each year of AIF operation, considering annual variations in the volume received and the costs that must be recovered. The present value of the AID unit charges range for $\$ 84$ to $\$ 420$ per cubic foot with a life-cycle average of about $\$ 177$ per cubic foot. When making decisions on cost factors and comparing alternatives, the lifetime average of $\$ 177$ per cubic foot is most meaningful.
\end{abstract}




\section{SUMMARY}

Under provisions of the Low-Level Radioactive Waste Policy Amendments Act of 1985 (LLRWPAA) and its predecessor law, states and congressionally-authorized compacts of states have sought over the past two decades to develop new low-level radioactive waste (LLRW) disposal facilities. Despite significant and costly efforts in these endeavors, no such facility has been sited, licensed, and actually constructed under provisions of the LLRWPAA and Title 10 of the Code of Federal Regulations Part 61 (10CFR61).

In 1995, the U.S. Department of Energy's National Low-Level Waste Management Program (the Program) described assured isolation as an alternative approach to long-term waste management that did not involve LLRW disposal with primary dependence on the natural characteristics of the site. The assured isolation concept involved placing LLRW in a licensed, engineered facility, from which the waste could be subsequently retrieved if necessary. The facility was described as remaining under license as long as radioactive materials were present at the facility. The conceptual facility relied on continuing inspection, monitoring, and preventive maintenance. These assumptions contrasted the required assumption for disposal facility licensing (under 10CFR61) that institutional control would be lost at 100 years following disposal facility closure and that the facility must, thereafter, meet LLRW disposal performance objectives without reliance on ongoing active measures.

From 1996 through 1998, the Program sponsored a study to estimate the life-cycle costs and evaluate the economics of assured isolation relative to LLRW disposal under 10CFR61. This investigation responded to a request from the State of Connecticut to assess the assured isolation concept's viability (Ch98). In that investigation, the characteristics of the assured isolation facility (AIF) and those of the LLRW disposal facility were constrained to be similar so the results would be comparable. No effort was made to optimize the AIF design characteristics in order to minimize lifecycle costs, although it was agreed that considerable design flexibility exists that could reduce estimated AIF life-cycle costs.

Early in 1999, the Texas Low-Level Radioactive Waste Disposal Authority (the Authority) requested the Program to sponsor an investigation to optimize principal design characteristics of the AIF concept and to estimate associated life-cycle costs. In this, the resulting investigation, the objective was to consider the cost saving effects of design changes that could be implemented without compromising the ability of the AIF to satisfy regulations believed to be applicable (as described in Si98). The Authority sought life-cycle cost information that they could compare to life-cycle cost estimates for the Texas LLRW disposal facility in 1997 (Ba99).

The optimized AIF consists of waste shipping containers being placed inside steel-reinforced concrete overpacks, which are in turn placed in steel-reinforced concrete vaults without an earthen cover system. The concrete vaults are designed to remain in service for hundreds of years with ongoing active maintenance. Maintenance will be required since the facility will remain under license as long as waste is present in the facility.

This report describes the design requirements, constraints, and assumptions that constitute the design basis. The design basis identifies required functions: retrievability; the ability to reduce or eliminate active maintenance; volume capacity and receipt rate; design codes; waste segregation and administrative controls; and financial assurance. The report provides a description of the key design features of the optimized AIF, namely, isolation units, concrete overpacks, isolation unit and site drainage systems, a preventive maintenance program, an isolation unit monitoring system, and an environmental monitoring system. The report defines the three periods of the AIF life cycle, namely, facility 
development, waste acceptance, and facility maintenance with preservation of future waste management options.

The cost estimating methodology is defined. It involved the preparation of constant-dollar, currentdollar, and present-value estimates. The major cost components during the three periods of the AIF life cycle are described.

The estimated present-value of life-cycle costs total about $\$ 318$ million. Of this amount, over 30 percent is attributable to the need to accumulate the financial assurance fund which allows waste management options to be implemented in the future.

The charge for waste received at the AIF in order to recover all costs and ensure proper facility function following the waste acceptance period was calculated for each year of AIF operation, considering annual variations in the volume received and the costs that must be recovered. The presentvalue of the AIF unit charges range from $\$ 84$ to $\$ 420$ per cubic foot with a life-cycle average of $\$ 177$ per cubic foot. When making decisions on cost factors and comparing alternatives, the lifetime average of $\$ 177$ per cubic foot is most meaningful. 


\section{ACKNOWLEDGMENTS}

The authors acknowledge and express their appreciation for the contributions of numerous other professionals in conducting the work documented in this report. Principal among these are Bill Newberry and Tom Kerr of the Department of Energy's National Low-Level Waste Management Program at the Idaho National Engineering and Environmental Laboratory and Ruben Alvarado and Susan Jablonski of the Texas Low-Level Radioactive Waste Disposal Authority. The experience and insights of these four people were invaluable resources for this work. 


\section{CONTENTS}

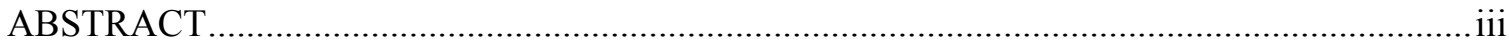

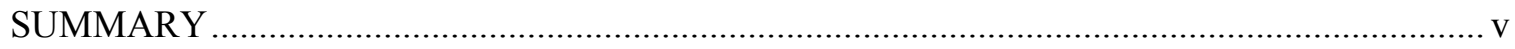

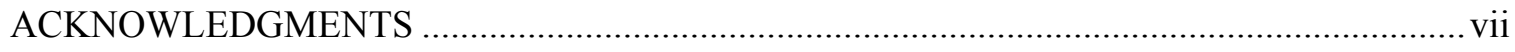

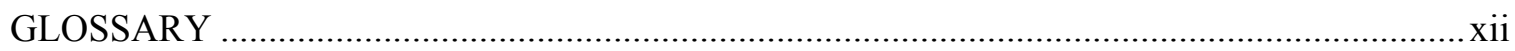

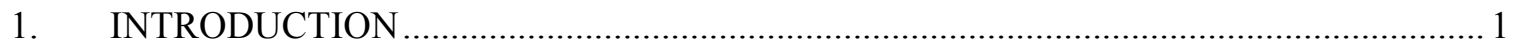

\section{Part 1}

Assured Isolation Facility Description

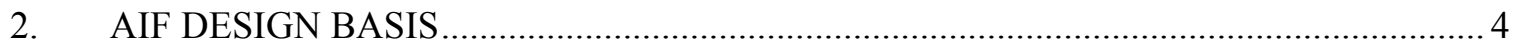

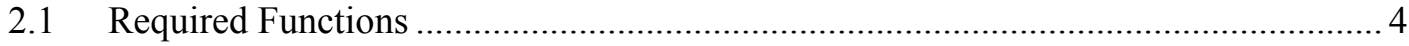

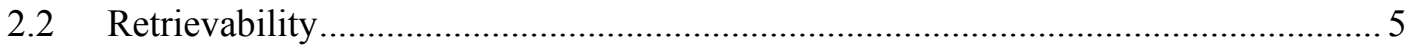

2.3 Ability to Reduce or Eliminate Active Maintenance ............................................ 5

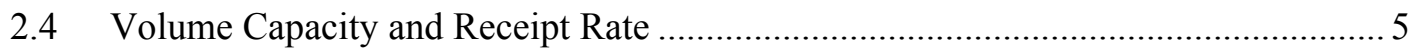

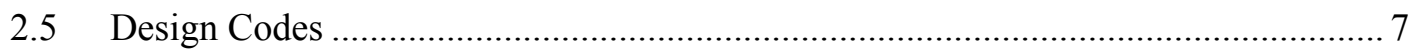

2.6 Waste Segregation and Administrative Controls ................................................ 7

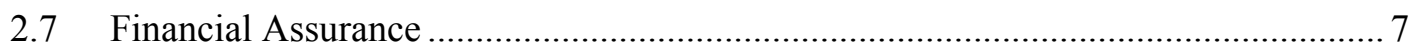

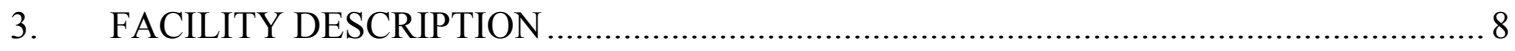

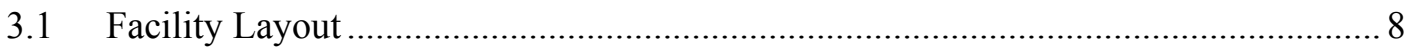

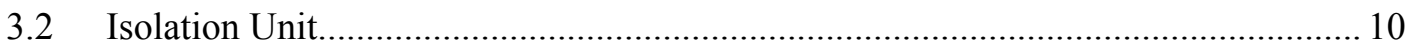

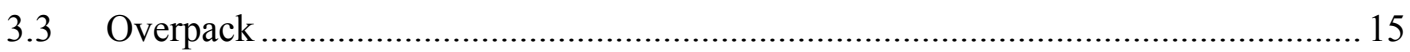

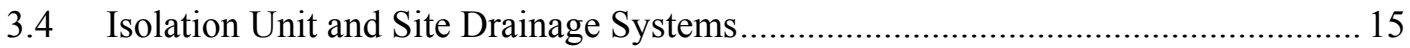

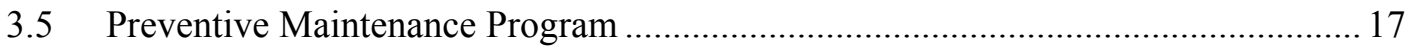

3.6 Isolation Unit Inspection and Monitoring System ............................................ 18

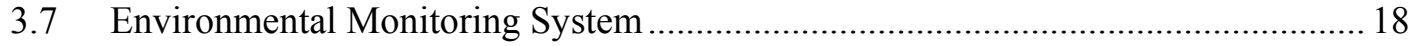




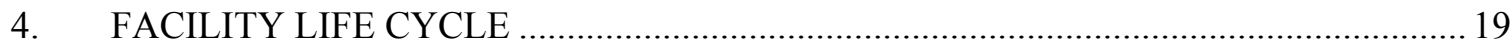

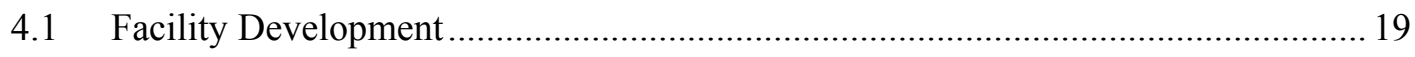

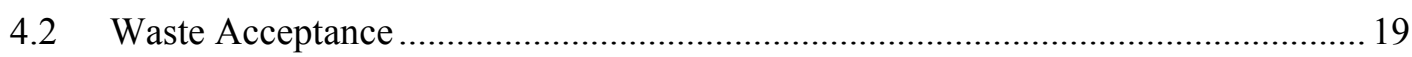

4.3 Facility Maintenance with Preservation of Future Management Options................. 20

Part 2

Assured Isolation Facility Life-Cycle Cost Estimate

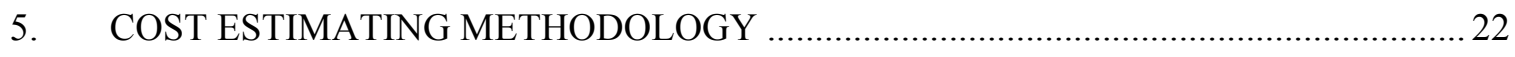

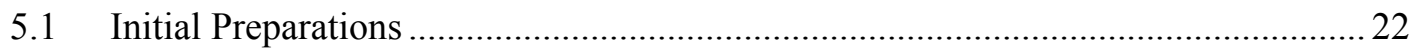

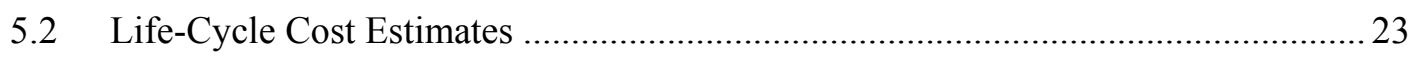

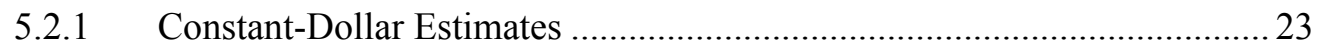

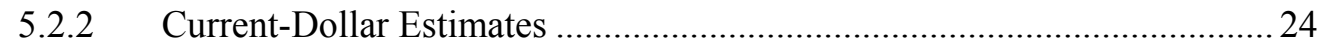

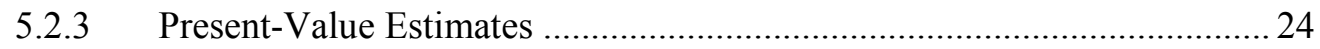

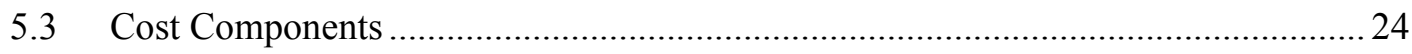

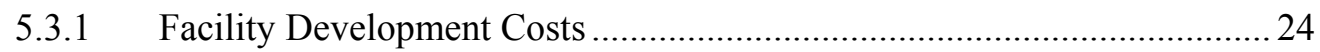

5.3.2 Isolation Unit Construction, Operation, and Closure ............................... 25

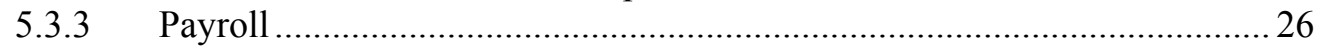

5.3.4 Construction Equipment Lease/Purchase ................................................26

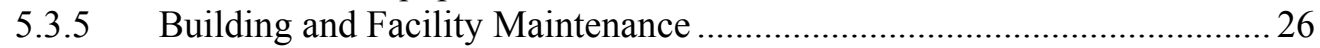

5.3.6 Utilities and Consumables .................................................................... 26

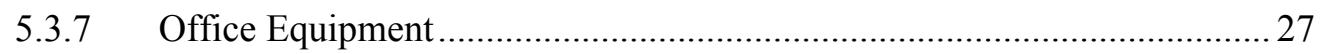

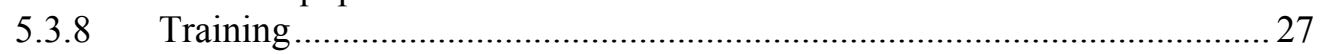

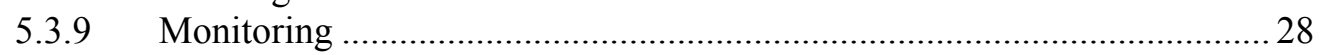

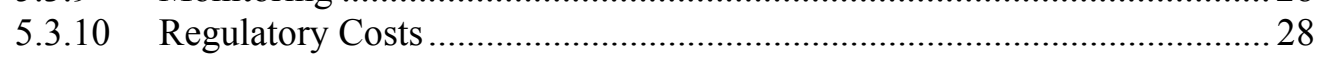

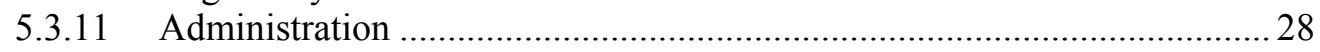

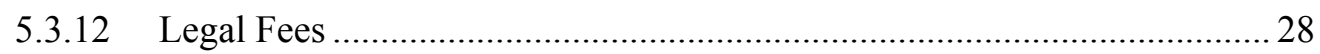

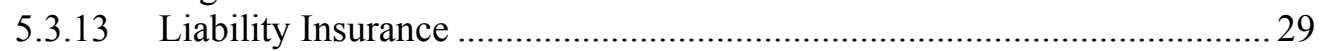

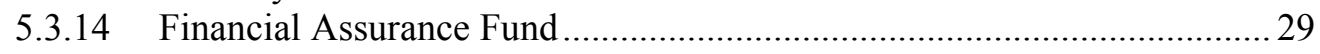

5.3.15 Contingencies and Incentive Payments.................................................2 29

6. OPTIMIZED AIF LIFE-CYCLE COST ESTIMATES …............................................. 30

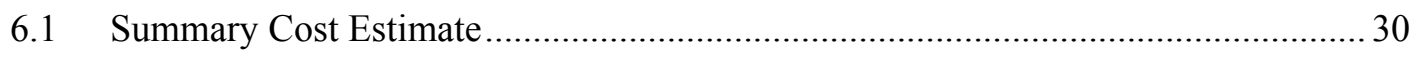

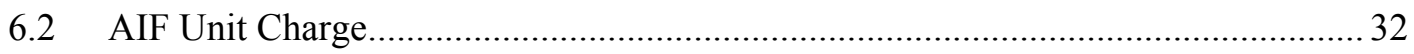




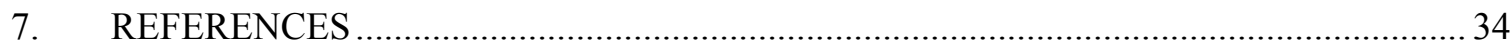

Appendix A - Peer Review Meeting Report

Appendix B - Cost Estimate Detail

\section{FIGURES}

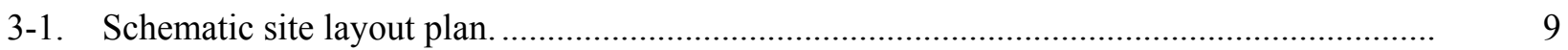

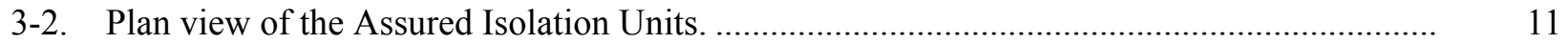

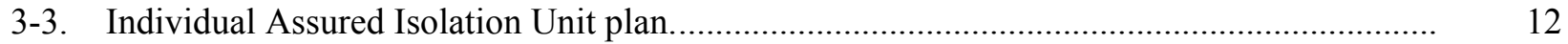

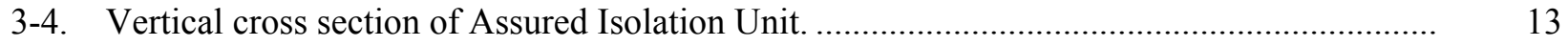

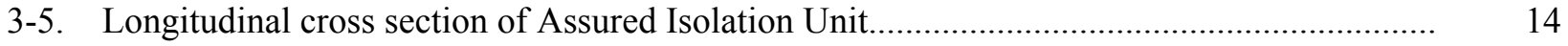

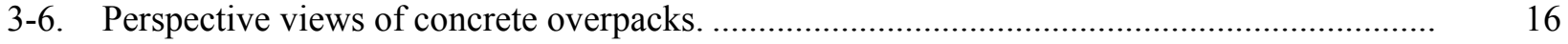

\section{TABLES}

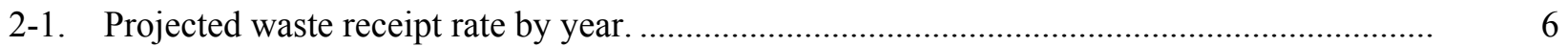

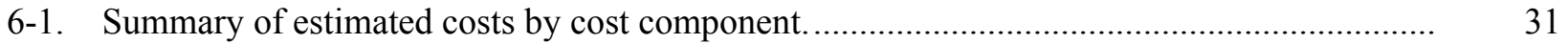

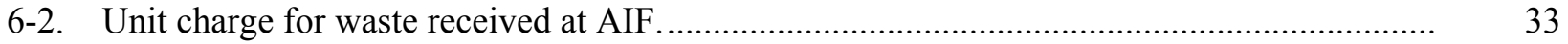




\section{GLOSSARY}

Active Maintenance:

AIF:

ACI:

ALARA:

Assured Isolation Facility:

Authority:

Constant-Dollar Cost Estimate:

Current-Dollar Cost Estimate:

DOE:

Isolation Unit:

Isolation Unit Monitoring:

LLRW:

LLRWPAA:

NRC:
Activities following the waste acceptance period that provide ongoing assurance that the facilities will continue to perform as designed and intended. Active maintenance includes routine care of the facility and its grounds, as well as repairs to keep the facility in good condition.

Assured Isolation Facility.

American Concrete Institute.

As Low As Reasonably Achievable.

A conceptual LLRW management facility designed for hundreds of years of service with the aid of active maintenance activities given that the facility will remain under license as long as radioactive materials are present at the facility.

Texas Low-Level Radioactive Waste Disposal Authority.

An estimate of costs with no allowance or account for inflation or time value of money. Generally smaller than current-dollar cost estimates but larger than present-value estimates.

An estimate of costs with allowance for inflation or escalation, but none for time value of money. Generally larger than constant-dollar cost estimates and much larger than presentvalue estimates.

U.S. Department of Energy.

Steel-reinforced concrete vault structure constructed at site grade that houses waste packages without the aid of an earthen cover system.

Activities designed to provide physical evidence to indicate the long-term performance of AIF isolation units. Includes monitoring of structural stability, structural performance, and potential leakage into isolation units.

Low-Level Radioactive Waste.

Low-Level Radioactive Waste Policy Amendments Act of 1985.

U.S. Nuclear Regulatory Commission. 
Present-Value Estimates:

Program:

Retrievability:

Environmental Monitoring:

$\mathrm{UBC}$ :

Waste Container:

Waste Package:
An estimate of costs with allowance for both inflation or escalation and for the time value of money. Generally smaller than both constant-dollar and current-dollar cost estimates.

DOE's National Low-Level Waste Management Program.

The intentionally preserved ability to retrieve waste packages from individual isolation units simply and with a minimum of radiation exposure to retrieval workers.

Activities designed to provide physical evidence whether radioactive constituents have escaped from AIF isolation units. Includes monitoring of groundwater, surface water, air, soils, sediments, vegetation, and animal life.

Uniform Building Code.

The container in which waste is shipped to the AIF. Generally has no long-term ability to remain structurally stable and to contain the waste.

Steel-reinforced concrete overpacks containing waste containers filled with solid LLRW. 


\section{Design Study and Cost Estimate for an Assured Isolation Facility in Texas}

\section{INTRODUCTION}

Under provisions of the Low-Level Radioactive Waste Policy Amendments Act of 1985

(LLRWPAA) and its predecessor law, states and congressionally-authorized compacts of states have sought over the past two decades to develop new low-level radioactive waste (LLRW) disposal facilities. Despite significant and costly efforts in these endeavors, no such facility has been sited, licensed, and actually constructed under provisions of the LLRWPAA and Title 10 of the Code of Federal Regulations, Part 61.

In 1995, the U.S. Department of Energy's National Low-Level Waste Management Program (the Program) described assured isolation as an alternative approach that did not involve LLRW disposal with primary dependence on the natural characteristics of the site. The assured isolation concept involved placing LLRW in a licensed, engineered facility, from which the waste could be subsequently retrieved if necessary. The facility was described as remaining under license as long as radioactive materials were present at the facility. The conceptual facility relied on continuing inspection, monitoring, and preventive maintenance. These assumptions contrasted the required assumption for disposal facility licensing (under 10CFR61) that institutional control would be lost at 100 years following disposal facility closure and that the facility must, thereafter, meet LLRW disposal performance objectives without reliance on ongoing active measures.

From 1996 through 1998, the Program sponsored a study to estimate the life-cycle costs and evaluate the economics of assured isolation relative to LLRW disposal (under 10CFR61). This investigation responded to a request from the State of Connecticut to assess the assured isolation concept's viability (Ch98). In that investigation, the characteristics of the assured isolation facility (AIF) and those of the LLRW disposal facility were constrained to be similar so the results would be comparable. No effort was made to optimize the AIF design characteristics in order to minimize lifecycle costs, although it was agreed that considerable design flexibility exists that could reduce estimated AIF life-cycle costs.

Early in 1999, the Texas Low-Level Radioactive Waste Disposal Authority (the Authority) requested the Program to sponsor an investigation to optimize principal design characteristics of the AIF concept and to estimate associated life-cycle costs. In this, the resulting investigation, the objective was to consider the cost saving effects of design changes that could be implemented without compromising the ability of the AIF to satisfy regulations believed to be applicable (as described in Si98). The Authority sought life-cycle cost information that they could compare to life-cycle cost estimates for the Texas LLRW disposal facility in 1997 (Ba99).

The Program contracted with Rogers and Associates Engineering (RAE) to conduct the investigation the Authority had requested, in part because RAE had prepared life-cycle cost estimates for a Connecticut disposal facility (Ba96) and AIF (Ch98) and also had prepared cost estimates for the proposed Texas LLRW disposal facility (Ba99). This report documents, in part, the results of that investigation. 
The Design Report documenting the results of the AIF design optimization project consists of two parts:

- $\quad$ Part 1: Assured Isolation Facility Description

- $\quad$ Part 2: Assured Isolation Facility Life-Cycle Cost Estimate.

A Cost Comparison Report rounds out the documentation for this investigation.

Parts 1 and 2 of the Design Report are bound together in this volume, while the Cost Comparison Report is bound separately. Part 1 of the Design Report addresses three primary topics:

1. Design basis and assumptions made in optimizing the AIF principal design features.

2. AIF principal design feature descriptions including text and sketches.

3. AIF life cycle, i.e., durations of development, initial construction, operation, and maintenance periods.

Part 2 describes the approach to estimating life-cycle costs and presents the estimated life-cycle costs, including constant-dollar, current-dollar, and present-value estimates.

The Cost Comparison Report summarizes the AIF life-cycle cost estimate for the optimized facility, updates and summarizes the Texas LLRW disposal facility cost estimates, and compares the Texas LLRW disposal facility life-cycle costs to those of the optimized AIF. 
PART 1:

ASSURED ISOLATION FACILITY DESCRIPTION 


\section{AIF DESIGN BASIS}

To ensure that design revisions chosen in this investigation are reasonable, it was necessary to define the general requirements the optimized AIF must satisfy. These requirements include provisions of applicable regulations (as described in Si98), constraints, assumptions, and other objectives. These requirements, constraints, and assumptions constitute the AIF design basis. The provisions of the design basis are summarized in this chapter.

\subsection{Required Functions}

In the Program's investigation of regulations judged to apply to the licensing of the AIF (Si98), seven functional requirements were identified. These required functions were assumed to apply to the optimized AIF.

The first functional requirement is that of minimizing water infiltration. Generally, this provision applies to the design of an earthen cover system. A cover system is usually provided in disposal facilities to direct water away from disposed waste and protect concrete disposal structures from deleterious weather conditions. The essence of this requirement is better captured by another functional requirement, described later.

The optimized AIF is required to ensure the integrity of the isolation unit (a structure provided to isolate LLRW from the environment). This requirement refers to the ability of the isolation unit to contain the waste constituents and to isolate them from the environment.

The optimized AIF must be structurally stable. This requirement refers to the need to ensure that the isolation structure is structurally sound over its entire service life. The service life of the optimized AIF was taken to be 300 years, although allowance was made by assuming the facility will be under constant care and benefiting from ongoing monitoring and the preventive maintenance program that will be required.

The AIF must prevent contact of water with waste emplaced in the isolation units. The structure provided as the isolation unit must ensure that rain water, snow, and runoff water cannot enter the isolation units coming into contact with the emplaced waste containers. If an earthen cover were included in the facility design, it would contribute to satisfying this requirement.

The AIF must provide adequate drainage. This requirement is a supplement to the requirement to prevent contact of water with emplaced waste. By providing adequate drainage in the facility design, assurance is provided that neither runon nor runoff water will contact the emplaced waste.

Occupational radiation exposures at the AIF must be maintained as low as reasonably achievable (ALARA). Although it cannot be rigorously demonstrated at this conceptual stage of facility design, that this requirement will be met, design decisions must nevertheless be made and operating procedures envisioned that will support meeting this requirement.

Finally, the AIF must also be monitored sufficiently to provide assurance that no waste constituent will be released from waste packages or from any isolation unit, without being detected in sufficient time to prevent its release from the AIF site boundaries. As presently envisioned, the multiple barriers between the waste and the environment, the extensive monitoring systems, and the active facility maintenance provide reasonable assurance that no waste constituents will be released to the environment. 


\subsection{Retrievability}

The optimized AIF must be designed and operated, and each isolation unit must be able to be closed in such a way as to preserve the ability to retrieve the waste at any time. In meeting this requirement, concern must be given to ensuring that, once access to the isolation unit has been gained, the waste packages can be retrieved simply and with minimum radiation exposure to workers. Design decisions involving the waste package and the isolation unit affect the ability to meet this requirement.

In this investigation, the ability to retrieve emplaced waste packages was assumed to be preserved by placing waste containers in modular concrete canisters (overpacks) and emplacing the resulting waste packages without backfilling the voids that remain between the waste packages. These canisters will be structurally designed to bear all loads typical of normal operating and handling activities. It was further assumed that the integrity of the concrete canisters will be monitored and that maintenance activities will be undertaken as required to ensure integrity and structural stability.

\subsection{Ability to Reduce or Eliminate Active Maintenance}

The viability of the assured isolation concept does not rely on reducing or eliminating active maintenance activities. However, the AIF design optimization study assumed that the level of active maintenance and monitoring could be reduced in the future, as long as doing so would not jeopardize the ability of the facility to isolate the waste and would satisfy all then-applicable regulations. One of the design goals is to provide a structure that will remain functionally intact for at least 100 years without reliance on active maintenance. This goal ensures a well-engineered facility.

In estimating AIF life-cycle costs, the level of effort and monitoring intensity was assumed to remain constant over the entire active maintenance period.

\subsection{Volume Capacity and Receipt Rate}

The volume of waste assumed to be delivered to the optimized AIF is the same as the design basis volume for the Texas LLRW disposal facility, for which life-cycle costs were estimated earlier in 1997 (TX96). This design volume is 1.8 million cubic feet plus an allowance of 10 percent to account for uncertainties. Of this total, 95 percent was estimated to be Class A waste, the balance being Class B and Class $\mathrm{C}$ waste. About 65 percent of the total volume coming to the AIF was assumed to be placed in cylindrical overpacks and 35 percent in rectangular overpacks (refer to Section 3.3).

The waste acceptance period for the AIF was assumed to last 30 years, while in the earlier estimate of life-cycle costs for the Texas LLRW disposal facility, the waste acceptance periods was assumed to last only 20 years (Ba99). Waste was projected to be delivered to the AIF at the varying annual rates shown in Table 2-1 (Ba99, TX96). 
Table 2-1. Projected waste receipt rate by year.

\begin{tabular}{|c|c|}
\hline Year of Operation & $\begin{array}{c}\text { Volume Received } \\
\text { (cu ft) }\end{array}$ \\
\hline 1 & 86,553 \\
\hline 2 & 111,979 \\
\hline 3 & 59,396 \\
\hline 4 & 36,328 \\
\hline 5 & 36,754 \\
\hline 6 & 34,171 \\
\hline 7 & 36,103 \\
\hline 8 & 36,529 \\
\hline 9 & 33,946 \\
\hline 10 & 32,938 \\
\hline 11 & 33,529 \\
\hline 12 & 31,111 \\
\hline 13 & 33,208 \\
\hline 14 & 36,362 \\
\hline 15 & 82,325 \\
\hline 16 & 75,326 \\
\hline 17 & 68,061 \\
\hline 18 & 57,785 \\
\hline 19 & 52,025 \\
\hline 20 & 44,759 \\
\hline 21 & 78,081 \\
\hline 22 & 78,081 \\
\hline 23 & 78,081 \\
\hline 24 & 78,081 \\
\hline 25 & 78,081 \\
\hline 26 & 78,081 \\
\hline 27 & 78,081 \\
\hline 28 & 78,081 \\
\hline 29 & 78,081 \\
\hline 30 & 78,081 \\
\hline TOTAL & $1,800,000$ \\
\hline
\end{tabular}


As shown in Table 2-1, the annual receipt rate is projected to vary from a low of about 31,000 cubic feet (in Year 12) to a high of about 112,000 cubic feet (in Year 2). In only four years is the annual waste receipt rate within 20 percent of the overall average annual rate of 60,000 cubic feet per year. About 50 percent of all years lie within 30 percent of the mean annual receipt rate (that is, between 42,000 and 78,000 cubic feet per year) and 90 percent within about 45 percent of the mean annual receipt rate (that is, between 33,000 and 87,000 cubic feet per year).

\subsection{Design Codes}

The AIF must be designed to satisfy all requirements of the Uniform Building Code (UBC), assuming the facility is located within a UBC Seismic Zone II. Since all of Texas lies in seismic zones of lower seismic hazard, this assumption is conservative and assures design adequacy. The AIF structures must also be designed to withstand the loading conditions specified in the American Concrete Institute standard for safety-related nuclear structures (ACI-349), as amplified in the U.S. Nuclear Regulatory Commission's (NRC) standard review plan for review of LLRW disposal license applications (NRC91).

Support structures and facilities must meet all prevailing code and local requirements. For the purpose of this investigation, these requirements were not enumerated.

\subsection{Waste Segregation and Administrative Controls}

Previous evaluations of existing regulatory requirements (Si98) concluded that all waste received for placement can be emplaced in the same isolation unit, irrespective of its waste class. Nevertheless, it was assumed that segregation by the external radiation levels at the surfaces of the waste packages would be desirable and perhaps necessary. For control of occupational radiation exposures, it was assumed that all waste packages containing Class B or Class C waste and Class A waste with high levels of external gamma radiation would be constrained to the bottom and interior regions of each isolation unit. Also, additional shielding may be required and would be provided as needed to protect workers entering the assured isolation unit. Through these administrative controls, interposing waste packages and shielding will reduce radiation levels to workers and members of the public in keeping with ALARA principles. Once waste emplacement activities within a given isolation unit cease, the risk of exposure is greatly reduced.

\subsection{Financial Assurance}

The future performance of the AIF focuses on assuring that future monitoring, maintenance, retrieval, and disposal costs will be funded without reliance on future revenues. In this investigation, it was assumed that funds sufficient to cover the AIF's most costly reasonable future scenario would be collected from AIF users at the time the waste is received at the facility. It was further assumed that these funds would be invested in secure government financial instruments to preserve their value and provide some small potential for growth, relative to inflation.

An evaluation of the relative magnitudes of maintenance costs and retrieval costs was undertaken. It was determined that one of the most costly future scenarios involved active maintenance for 100 years after the waste acceptance period, followed immediately by retrieval and subsequent disposal in a licensed LLRW disposal facility. This conservative scenario became the basis for estimating the level of financial assurance that would be provided. 


\section{FACILITY DESCRIPTION}

The design features of the optimized AIF are similar to those previously considered for others (Ch98). However, their characteristics have been modified so that the facility can be constructed less expensively and so that active monitoring and preventive maintenance can be accomplished easily.

The key design features of the optimized AIF include:

- Isolation Unit

- Overpack

- Isolation Unit and Site Drainage Systems

- Preventive Maintenance Program

- Isolation Unit Inspection and Monitoring System

- Environmental Monitoring System

In this chapter, AIF layout developed for this investigation is briefly described. The key design features are also described, with particular attention given to the description of the isolation unit.

\subsection{Facility Layout}

The AIF is situated on a 30 - to 60 -acre parcel of land of sufficient size to provide a 100 -foot wide strip of owner-controlled land around the isolation units themselves, as shown very simply and conceptually in Figure 3-1. An additional three-acre administrative area is provided where support facilities are situated. Typical support facilities include: administration building, operations support building, maintenance building, waste receiving and inspection facilities, waste transfer and handling building, and other lesser buildings, facilities, and utilities.

Access to the facility is controlled by a perimeter fence with gates as required. Only persons with legitimate needs to be present in the radiation controlled area will be admitted, and then only with appropriate training, personnel protection equipment, preparation of pertinent records, and radiation monitoring devices.

The assumption was made that contours at the site are regular with generally gentle slopes. It was also assumed that prudent siting criteria would have caused areas to be avoided where significant natural hazards (such as unusual seismicity, flooding potential, large upstream drainage areas, and natural slope instabilities) are likely to exist. 


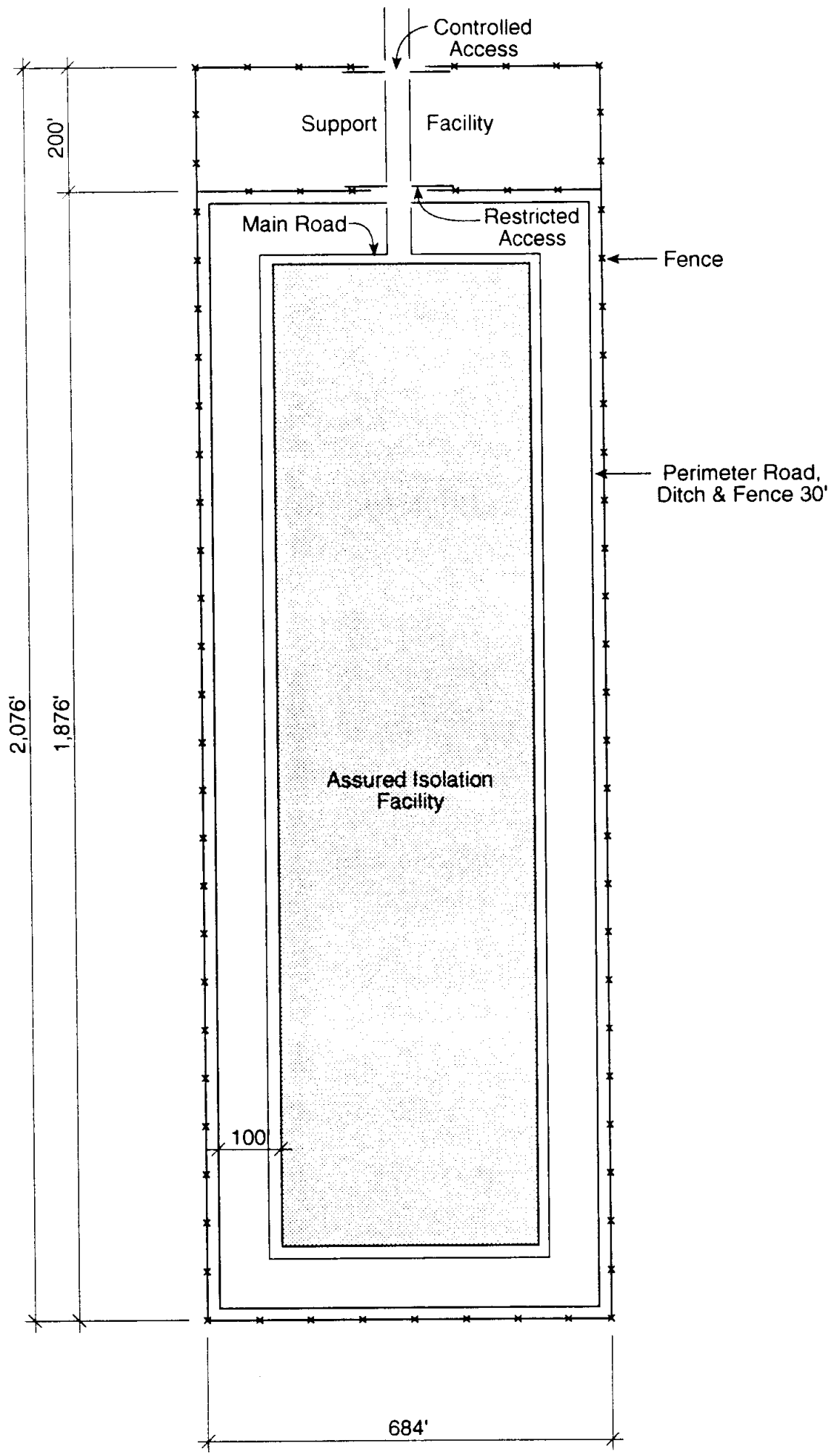

RAE - 106736

Figure 3-1. Schematic site layout plan. 


\subsection{Isolation Unit}

The most obvious design features of the optimized AIF are the isolation units that house the individual waste packages. The facility consists of 16 individual isolation units arranged in an array two units wide by eight units long, as shown in Figure 3-2. The array of isolation units is approximately 1,600 feet long and 425 feet wide. A central access aisle is situated between the two ranks of isolation units and facilitates access to each isolation unit for placement of waste packages and inspection/maintenance activities.

Each isolation unit is about 200 feet by 200 feet, as depicted in Figure 3-3, and will receive waste deliveries for approximately two years. Structural support is provided by a system of interior and perimeter columns that support the roof beam system. Columns are about 18 -inches square and are situated on roughly 29 -foot centers.

Each isolation unit will accommodate about 400 cylindrical and about 250 rectangular concrete overpacks, as well as those placed in the central "high-gamma room." In all, a total of nearly 124,000 cubic feet of waste can be placed in each isolation unit.

In the central portion of each isolation unit, a room consisting of concrete masonry unit (CMU) walls is constructed to receive waste packages containing Class B waste, Class C waste, or Class A waste with elevated external gamma radiation levels. This room is situated centrally so the radiation from the packages placed therein will be shielded by other waste packages with lower radiation levels. This "highgamma room" will accommodate a single tier of about 28 cylindrical and about 13 rectangular concrete overpacks, as illustrated in Figure 3-3. Additional waste packages containing Class A waste with low levels of external gamma radiation could be placed on top of the high gamma waste packages to provide additional radiation shielding.

Around the perimeter of each isolation unit, a human access aisle is reserved to facilitate remote monitoring, inspection, and maintenance activities. Human access to the isolation unit can be obtained through the vehicle doorway or through two additional 3-foot by 7-foot human access doorways that open into the central access aisle. Vehicular access to the isolation unit is through a single doorway that is 20 feet wide and 16 feet tall. This opening is sized to allow a forklift bearing a filled concrete overpack (or waste package).

The exterior of the array is cast-in-place steel-reinforced concrete walls, as shown in Figure 3-4. The interior height of the isolation unit ranges from about 25 feet to about 30 feet. With waste packages placed two tiers high within the isolation units, adequate clearance exists between the top of the emplaced waste packages and the bottom of the roof beam system to allow waste packages to be conveniently handled.

Provisions will be made to support operation of both an overhead crane (refer to Figure 3-5) and forklifts within each isolation unit. The overhead crane will be used to emplace waste packages into the "high-gamma room", while the forklift will be used to transport and emplace other lower-gamma packages outside the "high-gamma room." Once an isolation unit is filled to capacity, the overhead crane will be removed for use in another isolation unit, thereby limiting equipment purchase costs. Should the need arise in the future for a crane in any filled isolation unit, it can be returned as easily as it was removed. 


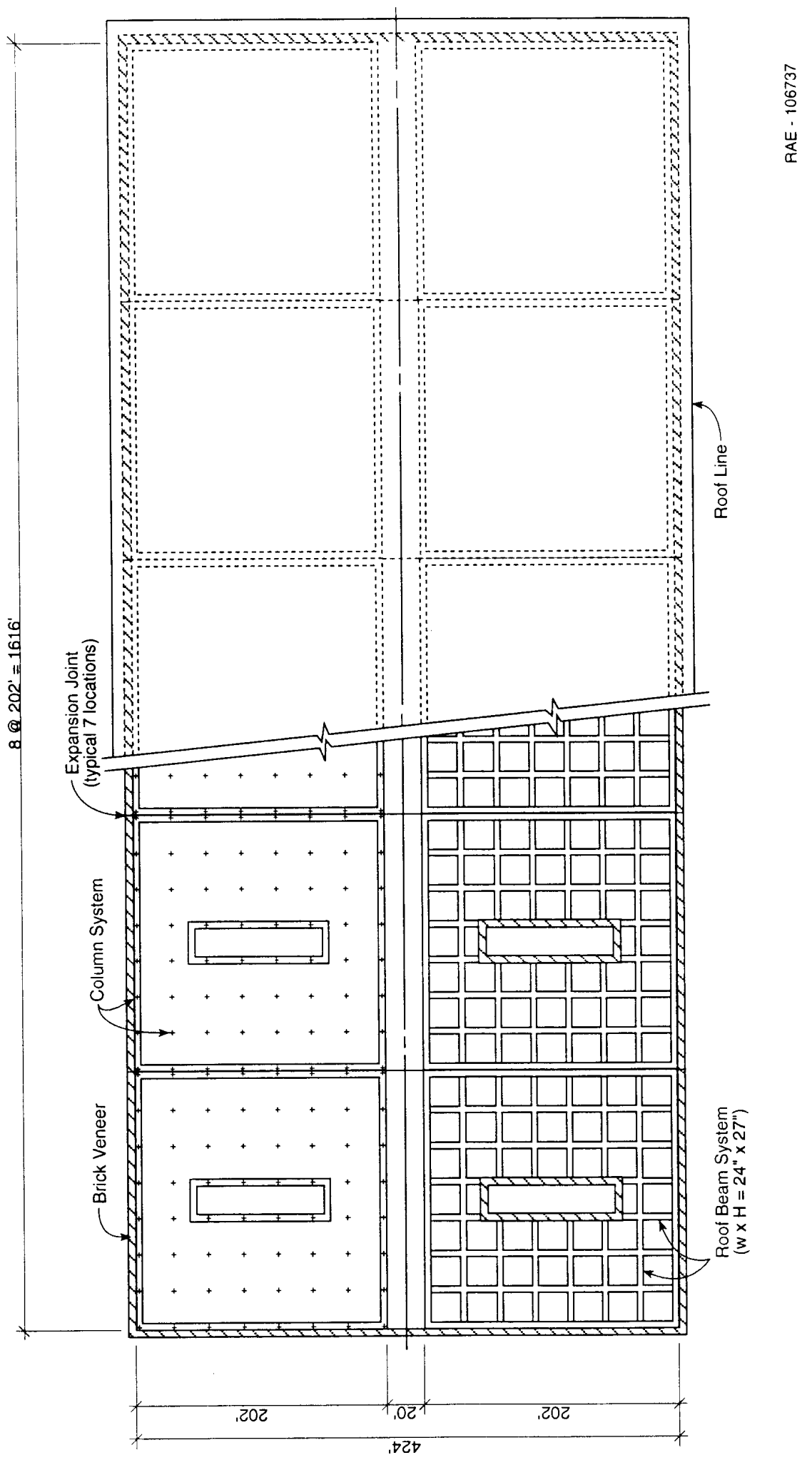

Figure 3-2. Plan view of the Assured Isolation Units. 


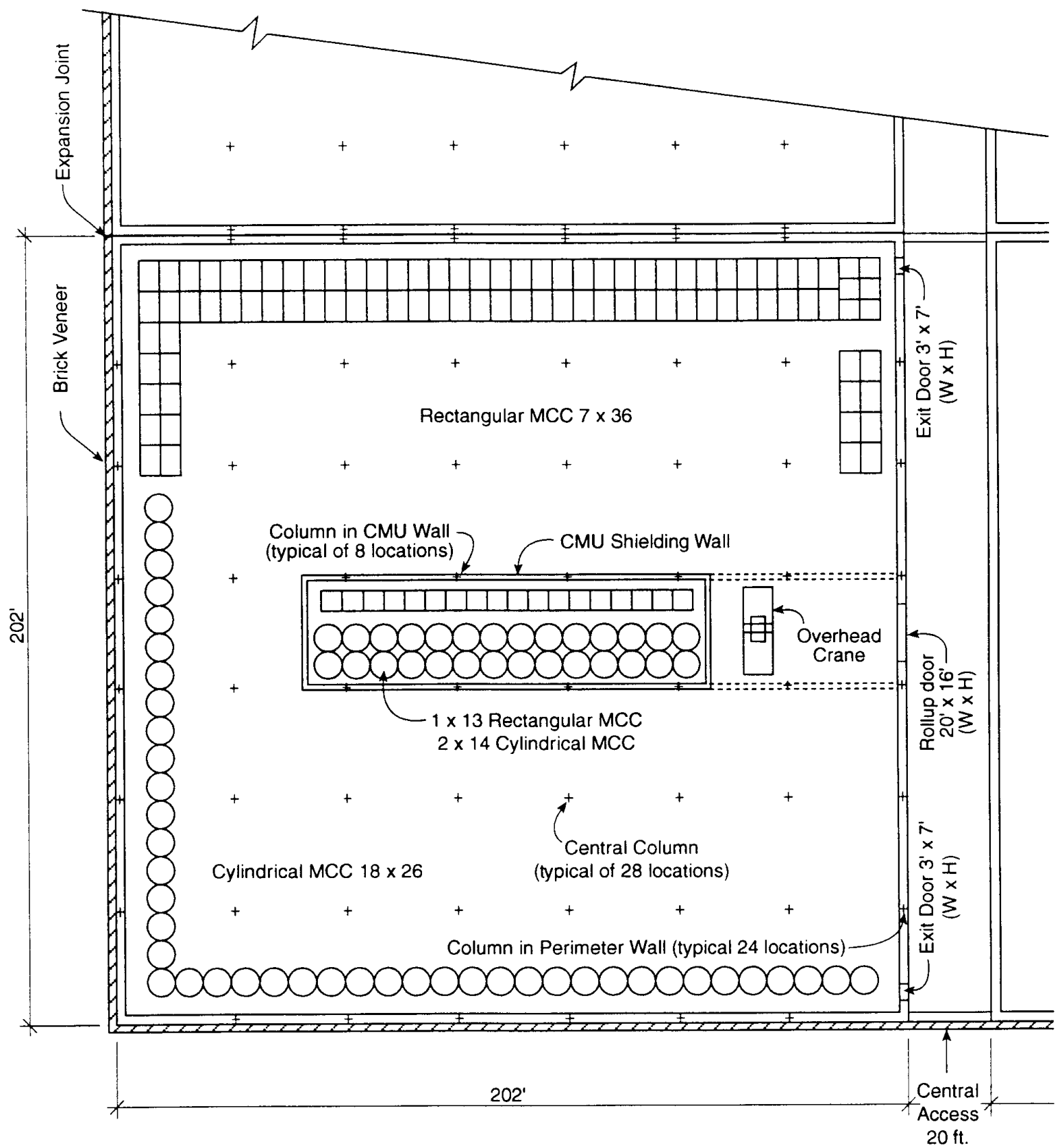

RAE - 106735

Figure 3-3. Individual Assured Isolation Unit plan. 


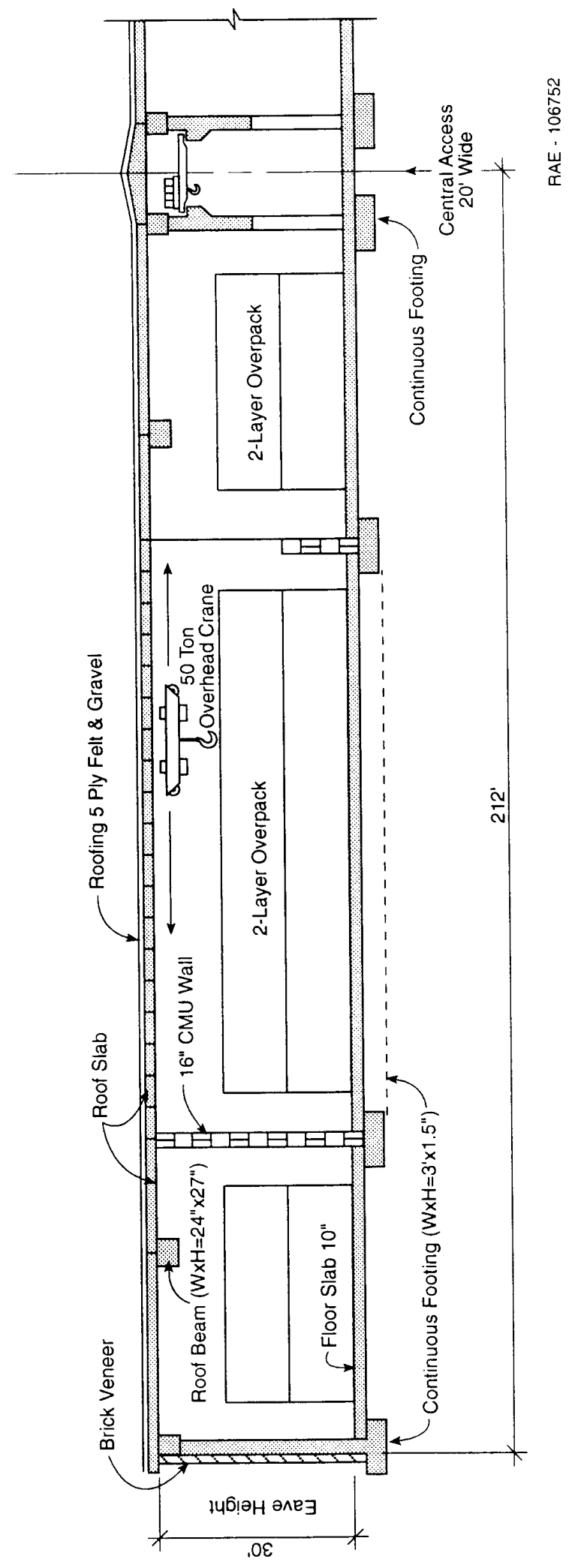

Figure 3-4. Vertical cross section of Assured Isolation Unit. 


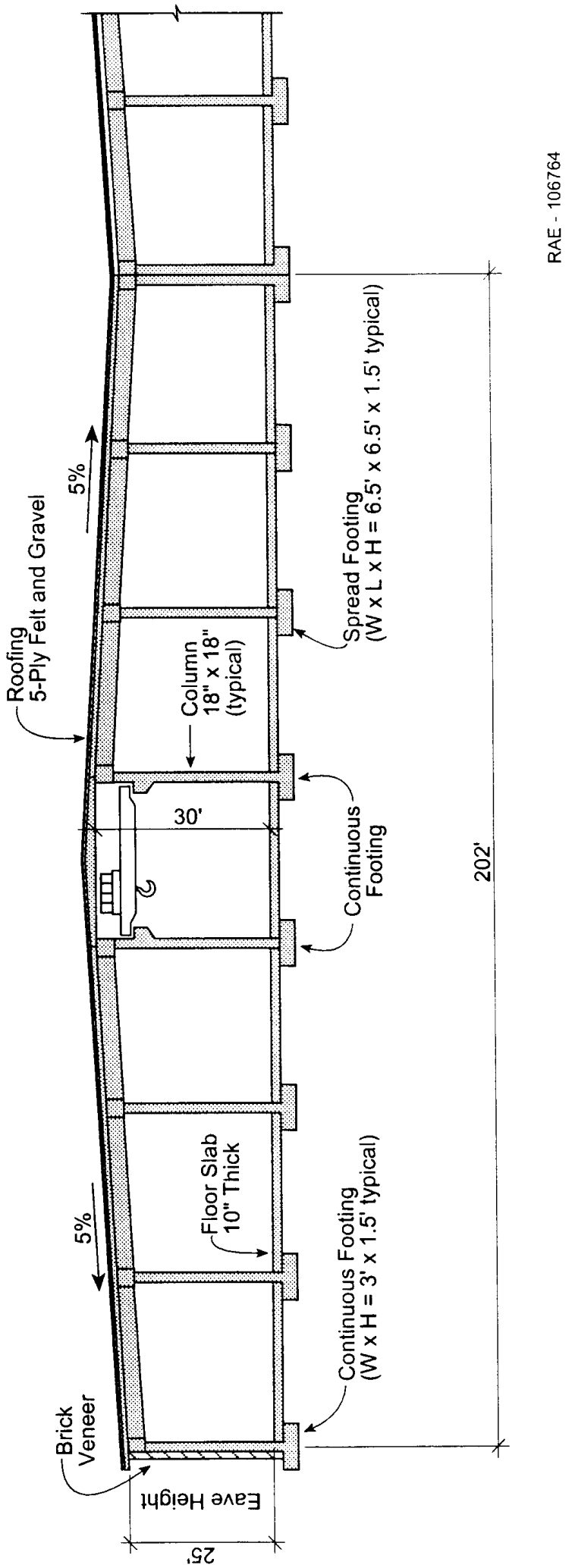

Figure 3-5. Longitudinal cross section of Assured Isolation Unit. 
Access to each isolation unit is from a covered access aisle located centrally between the two ranks of isolation units, as shown in plan in Figure 3-2 and in section in Figure 3-4. This access aisle is 20 feet wide and 30 feet tall, which is sufficiently large to allow all waste packages and handling vehicles unencumbered access.

The roof of each isolation unit is composed of pre-fabricated roof slabs and cast-in-place beams. The gaps between slabs are covered with a 2-inch-thick fiber-reinforced concrete topping with water stops and grout to prevent water from entering the isolation unit. The roof is also provided with a five-ply felt and gravel waterproofing system to further ensure that water will not enter the isolation unit.

Figure 3-5 shows that the roof will be vaulted and provided with a modest side slope to form swales between adjacent isolation units. Consequently, the longitudinal slope of the swale will be from the center to the edge, with provisions for drainage from the roof to drains that are monitored to ensure that no radiological contamination is present in any water on the site.

\subsection{Overpack}

Waste will arrive at the AIF in a variety of waste shipping containers. Although these containers are qualified as shipping containers, it was assumed that they could not be relied upon to contain waste for long periods of time. All shipping containers received at the AIF will therefore be placed in concrete overpacks that will remain structurally stable and capable of containing waste for many decades and perhaps centuries. These concrete overpacks provide greater assurance that the waste can be retrieved with a minimum of special handling or equipment.

The concrete overpacks take two configurations: cylindrical and rectangular. The cylindrical overpack has a nominal outside diameter of 100 inches ( 8 feet 4 inches) and an outside height of 108 inches (9 feet), as depicted in Figure 3-6. The structural elements of the overpack are steel-reinforced concrete. The walls are 4 inches thick, while the roof and minimum floor thicknesses are 6 inches. The internal dimensions are sufficient to accommodate two layers of seven 55-gallon drums, one cask liner, or one high-integrity container (HIC). It was projected that about 65 percent of all waste volume will be delivered to the AIF in containers that will be placed into cylindrical overpacks.

The rectangular overpack has nominal outside dimensions of 88 inches ( 7 feet 4 inches) in length, 114 inches (9 feet 6 inches) in height, and 64 inches ( 5 feet 4 inches) in width, as depicted in Figure 3-6. The structural elements of the overpack are steel-reinforced concrete. The walls are 7 inches thick, while the roof and minimum floor thicknesses are 6 inches. The internal dimensions are sufficient to accommodate two B25 boxes. It was projected that about 35 percent of all waste volume will be delivered to the AIF in containers that will be placed into the rectangular overpack.

\subsection{Isolation Unit and Site Drainage Systems}

Each isolation unit and the site is provided with drainage components to conduct precipitation, runoff, and surface water away from the isolation units and emplaced waste packages. The isolation unit structures themselves effectively perform the function of draining water away from the emplaced waste by standing as a substantial barrier between any water at the site and the emplaced waste packages. They are also provided with waterproofing features, such as roofing materials and coatings, that further ensure that water will not leak through construction or expansion joints to enter the isolation units. The interior of the isolation units will also be provided with monitoring systems (as described below), floor drains, and leakage detection systems to provide additional assurance that waste constituents will not be released from the isolation units. 


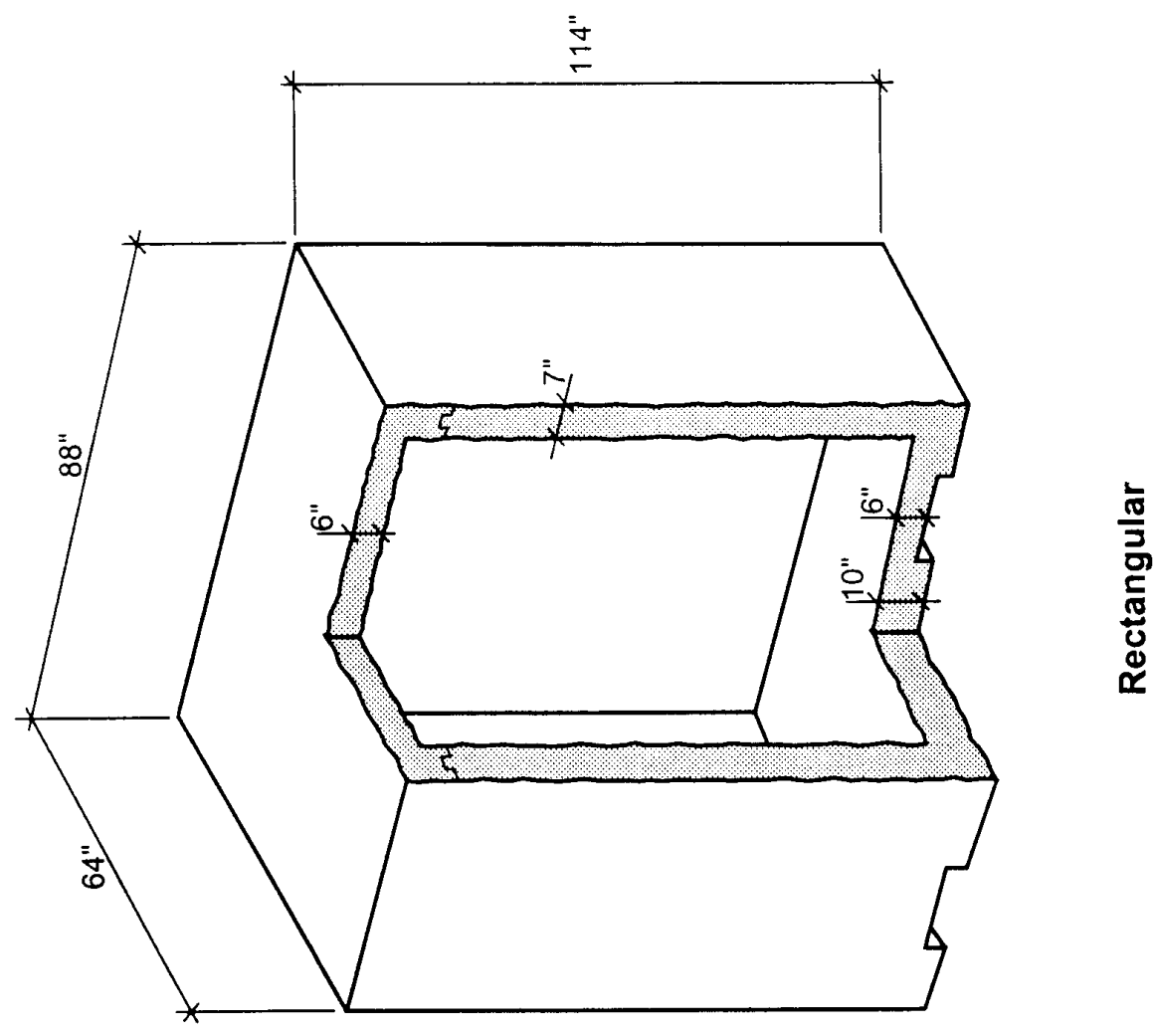

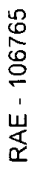

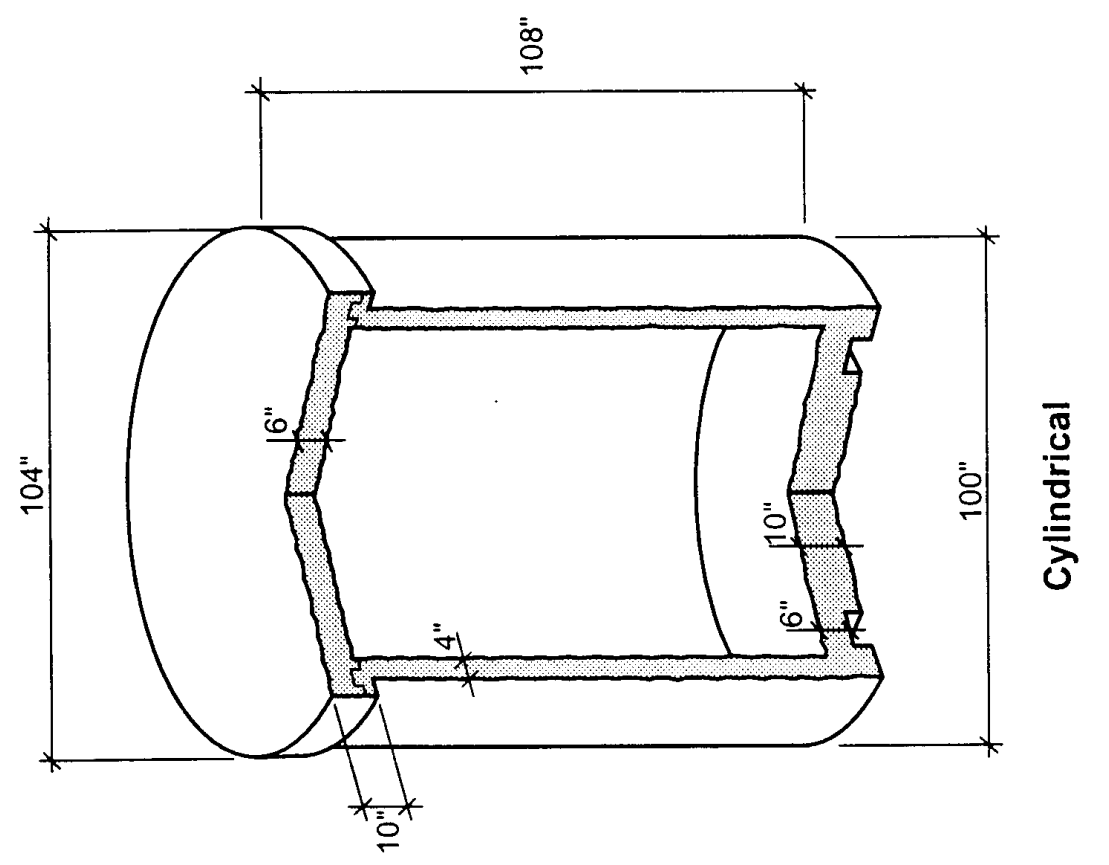

Figure 3-6. Perspective views of concrete overpacks. 
The site will be provided with perimeter berms and ditches to direct any water that may run onto the site from upstream areas away from the isolation units. Although explicit siting requirements do not exist at this time for locating an AIF, it was assumed that the facility would not be located in areas within the 100-year flood plain. Thus, providing protection against runon can easily be designed.

The site drainage features and components include the waterproofing materials on exterior surfaces of the isolation unit, sloped roofs, exterior drains, final site grading, drainage ditches and channels. To the extent required to satisfy stormwater pollution protection requirements, a retention pond may be provided. This pond will only be required to handle non-contaminated stormwater--not radioactive materials.

By conducting water away from isolation units and emplaced waste, assurance is provided that the potential for infiltration of water into isolation units will be minimized, that contact of water with emplaced waste packages will be prevented, and releases of radioactive materials from the isolation units via water will be prevented.

\subsection{Preventive Maintenance Program}

Although preventive maintenance is not normally considered a design feature, it is a prominent characteristic of the AIF concept and is therefore briefly described here. An important feature of the AIF is that it will remain under active license as long as radioactive materials are present at the facility. Because of the active license status, the licensee will remain responsible to conduct all activities required to protect the environment, workers, and the public against the effects of radiation and to remediate any deficient condition. Under terms of the active license, the licensee would be required, among other things, to take corrective or mitigative measures when conditions are encountered that might allow release of radiation or radioactive materials to the environment.

Many corrective or mitigative measures constitute preventive or ongoing active maintenance. Those that serve the purposes of maintaining the facility include such activities as:

- $\quad$ Regularly inspecting concrete conditions

- $\quad$ Periodically painting exposed concrete surfaces

- $\quad$ Repairing degraded concrete as required

- $\quad$ Periodically repairing or replacing roofing systems

- $\quad$ Responding to evidence of water leakage into or out of isolation units

- $\quad$ Responding to evidence of radioactive releases from waste packages or isolation units

- Responding to evidence of other undesirable or unacceptable conditions on the interior of isolation units

- $\quad$ Maintaining isolation unit and site drainage systems

- $\quad$ Maintaining site support facilities and peripheral systems 
- Inspecting and maintaining active systems intended to monitor the isolation units and the environment in the vicinity of the AIF

- $\quad$ Inspecting and maintaining perimeter fencing

- Undertaking any other activities and projects that ensure that the AIF will accomplish its purpose of isolating the waste from the environment.

These preventive ongoing active maintenance activities will provide continuing assurance that radioactive materials will not be released from the isolation units.

Furthermore, by performing these maintenance activities, the licensee provides ongoing opportunities for the regulatory agency to observe, inspect, and audit the activities onsite to ensure that they comply with license requirements. Through this process of ongoing compliance oversight, the regulatory agency will have ample opportunities to identify other activities or conditions that could lead to radioactive releases or other outcomes it deems unacceptable. Upon identifying such an activity or condition, the regulatory agency can impose additional requirements or license conditions to preclude unacceptable outcomes and to monitor the effectiveness of planned and new requirements.

\subsection{Isolation Unit Inspection and Monitoring System}

Each isolation unit will be provided with monitoring equipment to ensure that its performance can be properly known. The isolation unit monitoring system will include components necessary to monitor the following:

- Structural Stability Monitoring System (including creep, fatigue, freeze-thaw damage, aging, abrasion, temperature changes, wetting and drying, radiation, and cracking)

- Isolation Unit Interior Inspection and Monitoring System (involving remote video inspection of exposed interior concrete surfaces, waste packages, potential water leakage, and accumulation of water or leachate on floor)

- Isolation Unit External Monitoring System.

The Isolation Unit Inspection and Monitoring System will provide assurance that the isolation units are performing as planned and intended and that appropriate information is available to support decisionmaking and remediation planning, should undesirable or unacceptable conditions be observed.

\subsection{Environmental Monitoring System}

The design of the AIF will also include components necessary to monitor environmental pathways to ensure that radioactive materials can be prevented from being released from the AIF. Instrumentation, equipment and sampling/monitoring points will be provided that will allow environmental media to be continuously monitored (as in the case of the atmosphere and radiation levels in the AIF vicinity) or intermittently sampled (as with groundwater, surface water, soil, flora, and fauna). Sampling and monitoring results will be examined and evaluated, and the acceptability of the AIF performance will be determined routinely. 
Under expected conditions, no releases to environmental media in the vicinity of the AIF are expected. Normal monitoring of environmental media will therefore provide assurance that the facility is performing as expected. Should unplanned releases occur from any isolation unit, the Isolation Unit Inspection and Monitoring System will identify the potential for release to the environment long before such a release could actually occur. In the intervening time, actions can be planned and taken to preclude the release to any environmental media.

\section{FACILITY LIFE CYCLE}

The life cycle of the optimized AIF consists of three time periods:

- Facility Development

- Waste Acceptance

- Facility Maintenance with Preservation of Future Management Options.

The AIF activities that characterize these times are discussed in the following sections.

\subsection{Facility Development}

The initial phase of the AIF life cycle includes all activities that are conducted in developing and actually constructing the facility. The activities involved in facility development include:

- $\quad$ Site Selection

- $\quad$ Site Characterization

- $\quad$ Facility Design

- $\quad$ Facility Licensing

- $\quad$ Facility Construction.

In the AIF cost estimates, the duration of the AIF development period was assumed to be five years. It is expected that the facility will be sited with less public opposition than would face a LLRW disposal facility, and much less site characterization information would be required to license the AIF than would be required to license a LLRW disposal facility under 10CFR61.

\subsection{Waste Acceptance}

Following initial facility construction, waste will be received at the facility. During this period of the AIF life cycle, the following activities will occur:

- Waste shipments arrive at the AIF and are inspected and accepted

- Waste containers are transferred to concrete overpacks 
- Waste packages (comprised of containers inside overpacks) are transferred to an isolation unit

- $\quad$ New isolation units are constructed

- $\quad$ Routine access locations to filled isolation unit remain open to facilitate inspection and maintenance

- All monitoring and maintenance activities are conducted throughout this period.

The Waste Acceptance period was assumed to last for 30 years, as opposed to the assumed 20-year operating life of the Texas LLRW disposal facility (Ba99). It was further assumed that the AIF would be licensed for no longer than 10 years, after which license term, the license would require renewal.

As waste deliveries conclude, the AIF was assumed to undergo a brief transition from actively receiving waste to simply housing the waste packages.

\subsection{Facility Maintenance with Preservation of Future Management Options}

Once all isolation units have been filled with waste, the only licensed activities at the AIF are the routine monitoring and maintenance activities described in previous sections of this document. For this investigation, the Facility Maintenance period was assumed to last for at least 300 years.

At some future time, the AIF concept might involve implementing a different management option for waste emplaced in the AIF. Future management options might involve:

- $\quad$ Recycling some materials

- $\quad$ Retrieving the waste for subsequent disposal at a LLRW disposal facility licensed under prevailing regulations

- Retrieving the waste after adequate time for radioactive decay and disposition elsewhere

- $\quad$ Reducing the level of maintenance and monitoring because the facility has been proven to be successfully isolating the waste

- Retrieval for further treatment or neutralization, if practical techniques become available

- $\quad$ Closure of the AIF in-place

- $\quad$ Other management options yet to be developed.

For the purpose of estimating the life-cycle costs, it was assumed that the level of maintenance and monitoring would remain constant over the entire 300-year Facility Maintenance period. 
PART 2:

\section{ASSURED ISOLATION FACILITY LIFE-CYCLE COST ESTIMATE}




\section{COST ESTIMATING METHODOLOGY}

The work described in this report was accomplished following an approach similar to that used in estimating the life-cycle costs of the Texas LLRW disposal facility. The approach is described in the following sections.

\subsection{Initial Preparations}

An initial technical working session was held that involved parties specifically interested in and knowledgeable about the AIF design optimization project. The outcome of this meeting was agreement on the AIF principal design features and the general facility configuration.

Based on the initial working session, an initial facility description and sketch were prepared for consideration by a Peer Review Group, convened to give guidance on the efforts to optimize the AIF design. The documents provided to the Peer Review Group, all meeting materials, and a brief report of the meeting are presented in Appendix A. Based on the Peer Review Meeting, the facility was further characterized and individual cost components were prepared.

All existing relevant documents, evaluations, and other related information were collected and reviewed. Of particular interest was information from the estimate of LLRW disposal life-cycle costs for the proposed Texas facility. The following Texas-specific and general resources were considered:

- $\quad$ RAE document entitled "Design and Analysis of the Texas LLW Disposal Facility Using Modular Concrete Canisters for All Waste" (including associated cost estimate spreadsheets), RAE-9150/1-1, dated September 1992

- $\quad$ RAE document entitled "Low-Level Radioactive Waste Projections for Texas, Maine, and Vermont," RAE-9433/2-1, dated November 1994

- $\quad$ RAE document entitled "Detailed Information Used in the Low-Level Radioactive Waste Projections for Texas, Maine, and Vermont," RAE-9433/2-2, dated November 1994

- $\quad$ Radian document entitled "Cost Estimate for the Texas Low-Level Radioactive Waste Disposal Facility in Sierra Blanca, Texas", dated July 1996.

The following general references were also used:

- $\quad$ "Means Site Work \& Landscape Cost Data", R.S. Means Company, Inc., 1996

- $\quad$ "Means Building Construction Cost Data", R.S. Means Company, Inc., 1996

- $\quad$ "Means Square Foot Costs", R.S. Means Company, Inc., 1996

- $\quad$ "Means Heavy Construction Cost Data", R.S. Means Company, Inc., 1996

- $\quad$ "Building Construction Cost Data", R.S. Means Company, Inc., 1996 
- $\quad$ "Means Site Work Cost Data", R.S. Means Company, Inc., 1988

- $\quad$ "Environmental Restoration: Unit Cost Book", ECHOS, 1995

- $\quad$ "Environmental Restoration: Assemblies Cost Book", ECHOS, 1995.

\subsection{Life-Cycle Cost Estimates}

Life-cycle costs were estimated by phase of the AIF life cycle. The three phases addressed are defined in Chapter 4.

The activities, equipment, materials, contract services and other cost components required in each phase of facility life were identified and associated costs were estimated. A conventional spreadsheet application (namely, Microsoft Excel) was used to tabulate significant facility characteristics, calculate quantities, tabulate unit costs, and consolidate information in the form of the cost estimate. For each cost component, the quantities and unit costs were estimated. The magnitude of each was calculated and its timing also estimated. Based on the magnitudes and timings, constant-dollar, current-dollar, and presentvalue estimates were prepared, as described below.

\subsubsection{Constant-Dollar Estimates}

For each cost element, the magnitude of the cost and the time it will be incurred were estimated. The magnitude of each cost was estimated assuming that all such costs over the life of the facility were incurred immediately. That is, no allowance was made for the effects on costs or values due to escalation. Costs were based on 1997 costs taken from standard unit cost references, consistent with the approach for estimating life-cycle costs for the Texas LLRW disposal facility (Ba99).

The individual cost magnitudes were estimated using one of three techniques: quantity estimate, scaling estimate, or judgment estimate. The magnitude of a cost element can be estimated using the quantity estimate if a well-defined basis exists for resources such as material, supplies, and manpower. For example, based on engineering designs, the quantities of such resources as cubic yards of soil, tons of reinforcing steel, cubic yards of concrete, and number of full-time equivalent equipment operators can be estimated. Once the quantities were known, the costs were estimated by multiplying the quantity by the unit cost (for example, dollars per cubic yard, dollars per ton, or dollars per person-hour).

Scaling estimates can be used where reasonably well established relationships between two related costs are known or can be inferred. For example, the cost of engineering a structure is frequently taken to be 10 percent of the cost to construct it, depending on the level of quality assurance and quality control required during design and construction. Once the cost to construct the facility is estimated through quantity estimates, the cost to design the facility is estimated to be 10 percent of the construction cost.

Finally, if neither quantity nor scaling estimates are justified by the level of definition in the cost element, it may be necessary to estimate the cost on the basis of experience or judgment. In these cases, information from others previously involved in similar activities was sought and found to be very helpful. 


\subsubsection{Current-Dollar Estimates}

Once the constant-dollar magnitudes and timings of cost elements were known, current-dollar estimates were prepared for the total annual costs only. The total constant-dollar estimate for a year was escalated by the appropriate number of years from 1997 at the assumed inflation rate of 3 percent per year, consistent with earlier estimates of life-cycle costs of the Texas LLRW disposal facility (Ba99).

Current-dollar estimates are always larger than constant-dollar estimates, when inflation is greater than zero, as is typically true. The longer a cost is delayed, the greater will be its current value.

\subsubsection{Present-Value Estimates}

Once the current-dollar estimates (magnitudes and timings) were known, their present-values were estimated. The current-dollar estimate was discounted using the estimated or assumed cost of capital for the appropriate number of years. The cost of capital was assumed to be 5 percent per year, or 2 percent in excess of the assumed inflation rate of 3 percent per year. This assumption is consistent with earlier estimates of life-cycle costs of the Texas LLRW disposal facility (Ba99).

Under normal and typical circumstances (where the inflation rate is positive and the cost of capital exceeds the inflation rate), present-value estimates are always smaller than constant-dollar estimates. Furthermore, the longer a cost is delayed, the smaller will be its present-value estimate.

\subsection{Cost Components}

The various cost elements addressed in the cost estimate are described in this chapter. The lifecycle costs of the optimized AIF were estimated for all phases, beginning with site and facility development activities. The costs included in this estimate are those associated with site and facility development, facility operation, construction of isolation units (needed to replace isolation units as they are filled), and facility maintenance and monitoring with future management options preserved.

\subsubsection{Facility Development Costs}

The facility development costs were based on the pre-operational costs of the Authority for the Faskin Ranch site near Sierra Blanca, Texas. These costs included the following:

- $\quad$ Site Selection

- $\quad$ Site Characterization

- $\quad$ Geotechnical Engineering

- $\quad$ Facility Design

- $\quad$ Other Analyses 
- $\quad$ Licensing

- $\quad$ Legal Costs.

These historical costs are presented in Table B-A.1 of Appendix B.

Also included are the costs associated with pre-operational construction activities, namely, support building construction, site preparation, and construction of the first two isolation units.

\subsubsection{Isolation Unit Construction, Operation, and Closure}

The costs of constructing isolation units, receiving, handling, and emplacing the waste in the isolation units, and maintaining the isolation units are significant cost-incurring activities. The details considered in estimating these costs for isolation units are described below.

As the capacity of the previously constructed isolation unit is depleted by waste emplacement, another must be constructed to allow waste emplacement operations to continue. In order to estimate the costs of constructing, operating, and maintaining an isolation unit, all activities involved in isolation unit construction were tabulated. Each activity was then characterized in terms of the types and quantities of materials, types of equipment, amounts of equipment time, types of workers, and levels of workers' effort required to complete it. Major activities in the life of an isolation unit are as follows:

- $\quad$ Prepare isolation unit floor

- $\quad$ Construct concrete support columns

- $\quad$ Construct concrete walls and roof system

- $\quad$ Construct interior walls for Class B and C waste

- $\quad$ Install overhead crane

- $\quad$ Purchase concrete overpacks

- $\quad$ Emplace waste.

For each of these activities, materials, equipment, and labor costs were estimated. Overhead and cost of capital were considered for each activity, as were the effects of location-specific cost indices.

The waste receipt rate at the AIF was assumed to be that listed in Table 2-1. Construction was assumed to be sequenced so that a new isolation unit would be available when the capacity of the previous one was depleted. The projected construction schedule was then used to project the schedule of annual costs of constructing, operating, and deactivating isolation units. 


\subsubsection{Payroll}

The cost of payroll for the Authority staff and facility workforce was estimated based on numbers and types of workers expected at the administrative offices and at the AIF. Salary and wage rates were set considering typical pay scales for various worker types. This payroll cost was based upon a total Authority staff of 27 persons. The fringe benefits were estimated to total 34 percent of the direct labor rate and the annual payroll cost determined.

\subsubsection{Construction Equipment Lease/Purchase}

The costs to procure, operate, maintain, and repair construction equipment at the facility were estimated considering the types of equipment required. For each type of equipment, the capital cost, operating cost, maintenance/repair cost, effective life, and annual usage were considered in estimating the annual cost. Major equipment included fork lifts, 50-ton overhead cranes, and on-site transfer vehicles.

\subsubsection{Building and Facility Maintenance}

Structural maintenance and repairs were estimated to have the greatest impact on building and facility maintenance costs. Other cost components included:

- $\quad$ Refuse Collection

- $\quad$ Painting

- $\quad$ Carpet Cleaning and Replacement

- $\quad$ Plumbing Maintenance

- $\quad$ Electrical Maintenance

- $\quad$ Mechanical Maintenance (HVAC)

- $\quad$ Fence Repair

- $\quad$ Landscaping and Grounds Maintenance.

\subsubsection{Utilities and Consumables}

The annual cost of utilities and consumables considered the following:

- $\quad$ Electricity Service

- Telecommunications Services, including Data Lines

- Water Service

- $\quad$ Office Supplies

- Maintenance Shop Supplies 
- $\quad$ Laboratory Supplies

- $\quad$ Safety Equipment

- $\quad$ Level D Clothing

- $\quad$ Level C Half-Face Respirators

- $\quad$ Coveralls and Boot Covers.

\subsubsection{Office Equipment}

The annual cost of office equipment was nominal compared to other costs. It considered the following:

- $\quad$ Computer System and Software Replacement

- $\quad$ Copier Replacement

- Television/VCR Replacement

- $\quad$ Facsimile Machine Replacement

- $\quad$ Miscellaneous Equipment Replacement.

\subsubsection{Training}

The cost of personnel training considered representative training activities, such as the following:

- $\quad$ Basic Radiation Training

- $\quad$ Radiation Worker Training

- $\quad$ Emergency Training Exercise

- $\quad$ OSHA 8-Hour Health and Safety Training for Supervisors

- $\quad$ OSHA 8-Hour Health and Safety Training Refresher

- $\quad$ OSHA 40-Hour Health and Safety Training

- $\quad$ Miscellaneous Training. 


\subsubsection{Monitoring}

The costs of the environmental monitoring program were based on the program description presented in the Texas LLRW Disposal Facility License Application. It involved the following types of sampling/analysis activities:

- $\quad$ Ambient Air Monitor Replacement

- $\quad$ Sampling Equipment Replacement

- $\quad$ Sampling Materials

- $\quad$ Air Particulate Analyses

- $\quad$ Groundwater Analyses

- $\quad$ Surface Water Analyses

- $\quad$ Soil Analyses

- $\quad$ Sediment Analyses

- Vegetation Analyses

- $\quad$ Mammal Tissue Analyses

- $\quad$ Radon Analyses

- Bioassays

- $\quad$ Environmental, Personnel, and Visitor TLD Analyses.

These estimated costs are similar to those expected of a LLRW disposal facility and are conservatively large.

\subsubsection{Regulatory Costs}

Regulatory costs consisted largely of fees to cover the cost of activities of the regulatory agency to inspect and monitor the facility. The cost of renewing the facility license every ten years was also included. An allowance was also made to terminate or transfer the license at the end of active isolation operations.

\subsubsection{Administration}

The annual administrative and operating budgets were estimated, exclusive of facility operations, to total $\$ 300,000$.

\subsubsection{Legal Fees}

Fees to cover unspecified legal activities were estimated to total $\$ 30,000$ per year. 


\subsubsection{Liability Insurance}

Liability insurance was assumed to be maintained throughout the waste acceptance period and the 300 -year active maintenance period. The annual premium was estimated to be $\$ 50,000$ in 1997 dollars. This liability insurance is meant to cover personal injuries and property damage that may be associated with routine operations.

\subsubsection{Financial Assurance Fund}

Annual contributions to the financial assurance fund were assumed to be collected during the waste acceptance period to ensure that sufficient funds will exist at facility closure to cover the costs of actively maintaining, monitoring, and inspecting the facility for 300 years. Also covered by the financial assurance fund are the costs of retrieving all waste emplaced at the AIF; disposing of retrieved waste in a future, as-yet unspecified, disposal facility; and decontaminating and decommissioning the AIF. This was determined to be the most costly series of events under future management options.

The maximum cost following cessation of waste acceptance depends on the cost to retrieve and dispose of emplaced waste relative to the cost to maintain and monitor the facility. In order to ensure that adequate financial assurance is provided, the timing of waste retrieval for final disposition was determined so that the costs would be maximum. Analyses demonstrated that this time would occur either immediately upon cessation of waste acceptance (or after some minimum period of isolation following waste acceptance) if the cost of retrieval were controlling or at the end of the 300-year Facility Maintenance period, if maintenance and monitoring cost were controlling.

Various future scenarios were considered to identify that set of future conditions that maximize the magnitude of costs after the waste acceptance period. The present-value of costs after the waste acceptance period is maximized when the emplaced waste is assumed to be retrieved and disposed of immediately following the waste acceptance period. The relative magnitude of all other facility maintenance and monitoring costs would have to be larger by two orders of magnitude for this conclusion to change.

An annual contribution of about $\$ 5,560,000$ was provided, based on the estimated costs of the maximum-cost set of activities (namely, monitoring, maintenance, waste retrieval, and waste disposal) following the waste acceptance period. At the end of waste acceptance operations, this fund will amount to nearly $\$ 370,000,000$, including interest earnings. The financial assurance fund was assumed to be invested in secure government bonds.

\subsubsection{Contingencies and Incentive Payments}

A contingency allowance of 20 percent of all costs was added to the subtotal of estimated costs, excluding the incentive payments to the local community and collections for the Financial Assurance Fund. This contingency allowance was included to account for uncertainties and unexpected conditions that could add to the actual facility operating costs.

Following current law and assumed policy, the facility was assumed to make annual payments to the host community totaling 10 percent of total facility annual revenues, including collections for the Financial Assurance Fund, during the Waste Acceptance period. 


\section{OPTIMIZED AIF LIFE-CYCLE COST ESTIMATES}

Based on the cost estimating methodology and the cost components described in Chapter 5, the optimized AIF life-cycle costs were estimated. Constant-dollar and present-value estimates are summarized in the following section. Also presented below are estimated AIF unit charges by year of waste acceptance.

\subsection{Summary Cost Estimate}

The 30-year costs estimated in constant-dollars and present-values are summarized in Table 6-1 (with detailed calculations presented in Appendix B). The facility development period was assumed to last for five years, during which time a total of about $\$ 8.8$ million will be spent in site selection, site characterization, facility design, and facility licensing. The cost of initial construction activities was estimated to be about $\$ 7.9$ million. In constant-dollars, estimated development costs total about $\$ 16.7$ million.

In present-value, development costs were estimated to total about $\$ 19.1$ million. The present-value estimate is larger than the constant-dollar cost estimate, contrary to typical expectations. This is because the developmental costs, except the initial construction costs are based on historical costs of the Authority as they were experienced in developing the proposed facility at the Sierra Blanca site over the past seven years. Because they were incurred in the past, they are "discounted to the future" which means they grow much like an account drawing interest.

Table 6-1 also summarizes the costs during the waste acceptance period that will be passed on to the generators who send their waste to the AIF. These costs include all operating costs and charges for costs that will be incurred after the waste acceptance period (via the financial assurance fund). The constant 1997 dollar costs that must be covered during the waste acceptance period total about $\$ 419$ million.

The present-value of costs that must be covered by revenues during the waste acceptance period, except the present-value of facility development costs, amounts to about \$298 million. The present-value of facility development costs increases the total life-cycle costs to be recovered, as shown in Table 6-1, to about $\$ 318$ million.

Examining the results summarized in Table 6-1 reveals that the two largest constant-dollar cost components constitute more than 60 percent of the total life-cycle costs and the largest six amount to over 90 percent of the total. The single largest cost component is the charge for the financial assurance fund, amounting to nearly $\$ 167$ million in constant-dollars, which constitutes nearly 39 percent of the total lifecycle costs. This fact is not surprising since it must include worst case allowances for the emplaced waste to be retrieved and disposed elsewhere in a licensed facility. Although not surprising, this fact does require additional explanation.

Under current market conditions at currently operating disposal facilities, the cost to dispose in 1997 dollars was estimated to be at least $\$ 400$ per cubic foot. For the nearly 2 million cubic feet to be disposed of, the disposal cost would total at least $\$ 800$ million, if it were disposed of today. However, for this investigation, it was assumed to be disposed of 100 years after the waste acceptance period, or 130 years from the time the AIF is opened. During the waste acceptance period, funds will be accumulated to cover the future costs of retrieving and disposing of the waste. These funds draw interest over the 130 years of the waste acceptance and maintenance periods. If the waste were retrieved and disposed of at 130 years, sufficient funds would exist to cover the escalated costs of retrieval and disposal. 
Table 6-1. Summary of estimated costs by cost component.

\begin{tabular}{|c|c|c|c|c|c|c|c|c|}
\hline \multirow{4}{*}{$\begin{array}{l}\text { Facility } \\
\text { Development }\end{array}$} & \multirow{2}{*}{$\begin{array}{c}\text { Cost Component } \\
\text { Pre-Construction }\end{array}$} & \multicolumn{2}{|c|}{$\begin{array}{c}\text { Constant-dollars } \\
(\$ 000)\end{array}$} & \multicolumn{2}{|c|}{$\begin{array}{l}\text { Percent } \\
\text { Of Period } \\
\text { Total } \\
\end{array}$} & \multirow[t]{2}{*}{$\begin{array}{c}\text { Present } \\
\text { Value } \\
(\$ 000) \\
\end{array}$} & \multicolumn{2}{|c|}{$\begin{array}{l}\text { Percent } \\
\text { Of Period } \\
\text { Total } \\
\end{array}$} \\
\hline & & $\$ 8,800$ & & 52.7 & & & 56.6 & \\
\hline & $\begin{array}{l}\text { Initial } \\
\text { Construction }\end{array}$ & 7,900 & & 7.3 & & 8,300 & 43.4 & \\
\hline & Period Total & & 16,700 & & 100 & 22,200 & & 100 \\
\hline \multirow[t]{16}{*}{$\begin{array}{l}\text { Waste } \\
\text { Acceptance }\end{array}$} & $\begin{array}{l}\text { Isolation Unit } \\
\text { Construction and } \\
\text { Waste } \\
\text { Emplacement }\end{array}$ & 95,600 & & 22.8 & & 78,200 & 26.3 & \\
\hline & Facility Payroll & 34,200 & & 8.2 & & 28,700 & 9.6 & \\
\hline & $\begin{array}{l}\text { Construction } \\
\text { Equipment } \\
\text { Lease/Purchase }\end{array}$ & 1,900 & & 0.5 & & 1,000 & 0.3 & \\
\hline & $\begin{array}{l}\text { Building and } \\
\text { Facility } \\
\text { Maintenance }\end{array}$ & 1,900 & & 0.5 & & 1,600 & 0.5 & \\
\hline & $\begin{array}{l}\text { Utilities and } \\
\text { Consumables }\end{array}$ & 21,700 & & 5.2 & & 18,200 & 6.1 & \\
\hline & Office Equipment & 400 & & 0.1 & & 300 & 0.1 & \\
\hline & Training & 1,000 & & 0.3 & & 700 & 0.3 & \\
\hline & Monitoring & 6,900 & & 1.7 & & 5,800 & 1.9 & \\
\hline & Regulatory Costs & 3,400 & & 0.8 & & 2,800 & 0.9 & \\
\hline & Administration & 9,000 & & 2.2 & & 6,000 & 2.5 & \\
\hline & Legal Fees & 900 & & 0.2 & & 800 & 0.3 & \\
\hline & Liability Insurance & 1,500 & & 0.4 & & 1,300 & 0.4 & \\
\hline & $\begin{array}{l}\text { Financial } \\
\text { Assurance Fund }\end{array}$ & 166,700 & & 39.9 & & 89,700 & 30.2 & \\
\hline & Contingencies & 35.0 & & 8.4 & & 26,500 & 9.8 & \\
\hline & $\begin{array}{l}\text { Incentive } \\
\text { Payments }\end{array}$ & 37.8 & & 9.1 & & 30,000 & 10.6 & \\
\hline & Period Total & & 419,000 & & 100 & $\$ 297,800$ & & 100 \\
\hline & GRAND TOTAL & & 435,800 & & - & $\$ 318,200$ & & - \\
\hline
\end{tabular}


The next largest cost component is the cost to construct isolation units and emplace waste packages (including the cost of concrete overpacks). This constant-dollar cost is about $\$ 96$ million, with a presentvalue of about $\$ 78$ million (26 percent of the total life-cycle costs). Following this cost component, four others are of similar magnitude, and substantially smaller. These are the incentive payments ( $\$ 38$ million in constant-dollars), contingency allowance (\$35 million in constant-dollars), facility payroll (\$34 million in constant-dollars) and utilities and consumables (\$22 million in constant-dollars).

\subsection{AlF Unit Charge}

The cost to generators for waste delivered to the AIF, or the AIF unit charge, is a very useful parameter. It is usually taken to be a cost per cubic foot, although other bases for allocating costs have been considered. In order to calculate this AIF unit charge, the present-values of costs to be recovered and the waste volumes expected for delivery must be known for each year of operations.

As in the earlier estimate of life-cycle costs for the Texas LLRW disposal facility and described in Section 2.4 of this report, the volume of waste was assumed to vary by year, based on recent information given by generators (Ba99). Not only do the annual disposal rates vary, but so also do the annual costs. Variations in costs by year occur because of varying schedules for constructing isolation units, equipment replacement schedules, and periodic relicensing activities.

The unit charge for waste received at the AIF was calculated as the quotient of the present-value of costs to be recovered in a year and the volume of waste to be received in that year. These unit charges are summarized in Table 6-2.

The AIF unit charge ranges from a low of $\$ 84$ per cubic foot in Year 28 of waste acceptance to a high of $\$ 420$ per cubic foot in Year 8 of waste acceptance. Over the entire facility life, the average AIF unit charge is $\$ 177$ per cubic foot.

The value of the escalated AIF unit charge was also calculated to reflect the effects of inflation. The escalated AIF unit charge ranged from $\$ 187$ per cubic foot in Year 1 of waste acceptance to $\$ 670$ per cubic foot in Year 14 of waste acceptance.

In calculating the expected unit charge to receive waste at the AIF, no effort was made to levelize this unit charge from year to year through some accounting means. Instead, the present-value of all costs to be recovered in a given year was assumed to be recovered by the volume of waste received during that year. In practice, such a simple system probably would be unworkable, since, for economic reasons, generators would hold onto waste in years when disposal costs are high (i.e., little waste is expected at the AIF) and ship in years when the disposal costs are low (i.e., large volumes are expected.) This would lead to unstable financial operation of the facility. When making decisions on cost factors and comparing alternatives, the lifetime average of $\$ 177$ per cubic foot is most meaningful. 
Table 6-2. Unit charge for waste received at AIF.

\begin{tabular}{|c|c|c|}
\hline Year of Operation & $\begin{array}{l}\text { Present-value of AIF } \\
\text { Unit Charge } \\
(\$ / \mathrm{cu} \mathrm{ft})\end{array}$ & $\begin{array}{c}\text { Escalated AIF Unit } \\
\text { Charge } \\
(\$ / \mathrm{cu} \mathrm{ft})\end{array}$ \\
\hline 1 & $\$ 187$ & $\$ 187$ \\
\hline 2 & $\$ 201$ & $\$ 211$ \\
\hline 3 & $\$ 231$ & $\$ 255$ \\
\hline 4 & $\$ 337$ & $\$ 390$ \\
\hline 5 & $\$ 327$ & $\$ 397$ \\
\hline 6 & $\$ 330$ & $\$ 421$ \\
\hline 7 & $\$ 305$ & $\$ 409$ \\
\hline 8 & $\$ 420$ & $\$ 591$ \\
\hline 9 & $\$ 300$ & $\$ 443$ \\
\hline 10 & $\$ 319$ & $\$ 495$ \\
\hline 11 & $\$ 284$ & $\$ 462$ \\
\hline 12 & $\$ 295$ & $\$ 504$ \\
\hline 13 & $\$ 269$ & $\$ 483$ \\
\hline 14 & $\$ 355$ & $\$ 670$ \\
\hline 15 & $\$ 134$ & $\$ 266$ \\
\hline 16 & $\$ 130$ & $\$ 270$ \\
\hline 17 & $\$ 192$ & $\$ 420$ \\
\hline 18 & $\$ 147$ & $\$ 338$ \\
\hline 19 & $\$ 155$ & $\$ 373$ \\
\hline 20 & $\$ 189$ & $\$ 477$ \\
\hline 21 & $\$ 149$ & $\$ 396$ \\
\hline 22 & $\$ 98$ & $\$ 273$ \\
\hline 23 & $\$ 96$ & $\$ 282$ \\
\hline 24 & $\$ 139$ & $\$ 426$ \\
\hline 25 & $\$ 91$ & $\$ 293$ \\
\hline 26 & $\$ 103$ & $\$ 348$ \\
\hline 27 & $\$ 128$ & $\$ 457$ \\
\hline 28 & $\$ 84$ & $\$ 314$ \\
\hline 29 & $\$ 85$ & $\$ 333$ \\
\hline 30 & $\$ 100$ & $\$ 412$ \\
\hline Lifetime Average & $\$ 177$ & $\$ 358$ \\
\hline
\end{tabular}




\section{REFERENCES}

Ba96 Baird R. D., et al, "Feasibility Study for Developing A Class-A-Only Low-Level Radioactive Waste Disposal Facility in Connecticut," Rogers and Associates Engineering Corporation for Connecticut Hazardous Waste Management Service, RAE-9406/2-1, Draft Report, January 1996.

Ba99 Baird, R.D., B.C. Rogers, and P.L. Walter, "Life-Cycle Cost Study for a LLW Disposal Facility in Texas," DOE/LLW-256, Rogers and Associates Engineering Corporation for DOE's National Low-Level Waste Management Program, August 1999.

Ch98 N. Chau, A.A. Sutherland, and R. D. Baird, "Life Cycle Costs for Disposal and Assured Isolation of Low-Level Radioactive Waste in Connecticut," DOE/LLW-246, Rogers and Associates Engineering Corporation for DOE's National Low-Level Waste Management Program, March 1998.

NRC91 "Standard Review Plan for the Review of a License Application for a Low-Level Radioactive Waste Disposal Facility," U.S. Nuclear Regulatory Commission, NUREG1200, Rev 2, January 1991.

Si98 Silverman, Donald J., Michael A. Bauser, and Robert D. Baird, "Licensing an Assured Isolation Facility for Low-Level Radioactive Waste," DOE/LLW-250, Morgan, Lewis \& Bockius LLP for DOE's National Low-Level Waste Management Program, July 1998.

TX96 Texas Low-Level Radioactive Waste Disposal Authority, "Texas Low-Level Radioactive Waste Disposal Facility; License Application," submitted to the Texas Water Commission [subsequently the Texas Natural Resource Conservation Commission], Revision 20, December 1996. 
APPENDIX A

PEER REVIEW MEETING REPORT 



\section{APPENDIX B}

COST ESTIMATE DETAIL 